\title{
Liberalizing the Global Supply Chain of Renewable Energy Technology: The Role of International Investment Law in Facilitating Flows of Foreign Direct Investment and Trade
}

\author{
Cees Verburg* \\ PhD Researcher, Groningen Centre of Energy Law, Faculty of Law, \\ University of Groningen \\ c.g.verburg@rug.nl
}

\section{Jaap Waverijn}

PhD Researcher, Groningen Centre of Energy Law, Faculty of Law, University of Groningen; Fellow, Platform on International Energy Governance j.j.a.waverijn@rug.nl

3.500.000.000.000 USD. That is the amount needed on an annual basis until the year 2050 to ensure that low-carbon energy supply will meet energy demand in that year according to the International Energy Agency. ${ }^{1}$ Financing

* The authors would like to emphasize that the names of the authors appear in alphabetical order, both have contributed equally.

** The Special Issue 'International Law for the Sustainable Development Goals' is a research outcome of the 2017-2018 Workshop Series 'International Law for the Sustainable Development Goals' organised by the Department of Transboundary Legal Studies, Faculty of Law, University of Groningen. Mando Rachovitsa and Marlies Hesselman led the organisation of these workshops. The series included 8 workshops which explored the role and relevance of international law to the implementation of the Sustainable Development Goals. The Special Issue includes some of the papers presented at the workshops and papers submitted to an open Call for Papers. More information is available at https:/www.rug.nl/rechten/ congressen/il4sdgs/.

1 International Energy Agency, Perspectives for the Energy Transition - Investment Needs for a Low Carbon Energy System (Bonn: IEA/IRENA, 2017), https://www.iea.org/publications/ insights/insightpublications/PerspectivesfortheEnergyTransition.pdf, accessed 1 November 2018, p. 8.

(C) CEES VERBURG AND JAAP WAVERIJN, 2019 | DOI 10.1163/23527072-00201001

This is an open access article distributed under the terms of the prevailing CC-BY license at the time of publication. 
and deploying renewable energy sources (RES) will be vital in the coming decades in light of attaining a range of Sustainable Development Goals (SDG) that were agreed upon by the international community, such as sustainable energy for all (SDG 7), sustainable economic growth (SDG 8), and mitigating the consequences of climate change (SDG 13). ${ }^{2}$ Given the magnitude of the required investments and the fact that large portions of state budgets are usually reserved for other policy objectives, it is beyond doubt that a significant part of the investments will have to be made by the private sector.

Indeed, the private sector already provided for go percent of the renewable energy investments in 2016 globally. ${ }^{3}$ This sector is not nearly as limited in deciding how to spread its investments as the government is. Major oil, gas and energy companies, some of which with revenues exceeding USD 100 billion a year, can be of great importance in realizing a shift towards investments in renewable energy projects. Moreover, while current numbers are difficult to ascertain, the investment portfolio of institutional investors who invest on behalf of their members, such as pension funds and insurance companies, was estimated at USD 160 trillion in recent history. ${ }^{4}$ Considering the size of the managed funds, institutional investors can play an important role and they have become more active in the renewable energy market recently. ${ }^{5}$ Other actors which are instrumental to develop large projects include banks and semi-public financial institutions such as development banks and export credit agencies. This is the case since companies borrow money to finance their activities as this allows them to invest in more projects at the same time, which should both increase their profits and spread their risks. In addition, there are usually tax benefits connected to interest payments which makes borrowing more attractive.

For large energy projects, with construction and operation costs of EUR 1-3 billion per project, expenditure for both debt and equity are typically high.

2 In addition, financing and developing renewable energy projects can also contribute to SDG 1 (no poverty), and SDG 9 (industry, innovation and infrastructure).

3 IRENA and CPI, Global Landscape of Renewable Energy Finance (Abu Dhabi: International Renewable Energy Agency, 2018), p. 8.

4 TheCityuk, 'UK Fund Management', April 2018, https://www.thecityuk.com/assets/2018/ Reports-PDF/fe6b3af4b4/UK-fund-management.pdf, accessed 1 November 2018, pp. 14-16.

5 REN21, Renewables 2017 Global Status Report (Paris: REN21 Secretariat2017), http://www.ren21 .net/wp-content/uploads/2017/06/17-8399_GSR_2017_Full_Report_0621_Opt.pdf, accessed 1 November 2018. Institutional investors do not enjoy unlimited discretion regarding their investment decisions. They are subject to fiduciary duties, which for different investors result in the formulation of different risk profiles. Moreover, in order to reduce risks and justify investment decisions, a diverse portfolio is most commonly assembled conform portfolio theory; Harry Markowitz, 'Portfolio Selection', Journal of Finance, 7/1: 77-91 (1952). 
For some developers, borrowing is a necessity because of a lack of equity. This does not have to be problematic. Especially when 'project finance' is used meaning that lenders only have recourse against the assets of the project - the percentage of debt tends to be high, usually between 50 and 80 percent of the total costs of a project ${ }^{6}$ and sometimes as high as $9^{0}$ percent. ${ }^{7}$ In the alternative of 'corporate finance' the debt percentages are usually lower and the exposure of project developers in this case extends beyond the project. It can be relatively expensive for project companies to attract debt using project finance in comparison to large corporations using corporate finance, especially when a project involves significant risks.

The primary reason to use project finance, which is often used in the RES sector, is that a company cannot afford to extend liability to all of its assets, as this would negatively impact its credit rating and therefore increase the cost of debt and limit debt capacity. ${ }^{8}$ Lenders therefore play an important role in the realization of projects as the capital they provide is instrumental. They can often dictate the terms on which they are willing to provide this capital, especially when competition is limited. Because of the large amounts of money involved, lenders generally require that they are granted comprehensive security packages and that a significant part of the cash flow of projects is to be used for debt payment obligations. ${ }^{9}$ Especially where the debt provided exceeds 70 percent of the total costs of a project, high debt payment obligations make the project relatively vulnerable to changes in cash flow..$^{10}$ This is why both investors and lenders ensure, through an elaborate risk assessment, that

6 Vicky Cox and Patrick Holmes, 'Principal Loan Finance Documentation' in John Dewar (ed.), International Project Finance Law and Practice (Oxford: Oxford University Press, 2015), p. 298.

7 Clive Ransome and Geoffrey Dunnett, 'Sources of Funding' in Dewar, International Project Finance Law and Practice, p. 62.

8 Because of their involvement in the global financial crisis, credit rating agencies are not relied upon as much. Legal separation of projects remains, however, of importance in light of limiting liability of other corporate assets and thereby protecting the cost against which the sponsors can attract capital. Roger McCormick, 'Project Finance' in Sarah Paterson and Rafal Zakrzewski (eds.), The Law of International Finance (Oxford: Oxford University Press, 2017), p. 777; Stefano Gatti, Project Finance in Theory and Practice: Designing, Structuring, and Financing Private and Public Projects (London: Elsevier Academic Press, 2013), p. 3 .

9 Philip Benger and Patrick Holmes, 'Ancillary Finance Documentation' in Dewar, International Project Finance Law and Practice, p. 463.

10 Cox and Holmes, 'Principal Loan Finance Documentation', pp. 299-300. This vulnerability is absent when corporate finance is used, because in that case the lenders have recourse against all assets of the company. This, of course, assumes that the company is 
the risks which can cause detrimental changes to the cash flow are minimized and, where possible, hedged. Another result of the high percentages of debt attracted is that a reduction of the cost of debt has a very significant impact on the levelized cost of electricity produced from RES projects. For example, taking common figures for an offshore wind farm, a decrease in the cost of capital by five percentage points, from ten to five percent as has approximately happened in the North Sea offshore wind sector, would result in a thirty percent decrease in the levelized cost of electricity over the lifetime of an installation. ${ }^{11}$ Therefore, making capital available at lower costs contributes significantly to the competitiveness of REs.

In particular for governments of countries that lack sufficient domestic financial resources or the required technology and knowledge, a primary concern is attracting private capital by increasing flows of foreign direct investment (FDI) to finance an energy transition. However, between 2013 and 2016, an average of 93 percent of global private renewable energy investments remained within the country of origin. ${ }^{12}$ This invites the question what issues determine whether or not private sector actors are interested to invest in or extend loans for cross-boundary REs projects. The main question that we will try to answer in this contribution is: How can investment treaties remove barriers to investment, as perceived by investors, in order to facilitate FDI and trade in the RES supply chain?

Undoubtedly, a successful energy transition will depend on the adoption of favourable legal frameworks that incentivize investments in the RES sector at both the national and international level. At the national level, one can think of support schemes, such as feed-in-tariffs (FITs). This contribution will, however, concern policy instruments that may contribute to flows of FDI at the international level and more specifically, investment treaties.

Our analysis is based on the theory that a supportive and predictable investment climate will attract additional investments at lower cost by eliminating

larger than the one project and has sufficient cash to, temporarily, deal with setbacks in cash flow from the project.

11 Giles Hundleby, 'LCOE - Weighted Cost of Capital, (WACC)', https://bvgassociates.com/ lcoe-weighted-average-cost-capital-wacc/, accessed 1 November 2018.

12 IRENA and CPI, Global Landscape of Renewable Energy Finance, p. 35. It should be noted that IRENA and CPI are not clear in the methodology used to reach this conclusion, while the methodology has significant impact on the calculation of the percentage of FDI. Many businesses operate worldwide and usually establish a physical and legal presence in the countries where they operate. 
barriers and reducing risks. ${ }^{13}$ This will primarily be explained from the investor's micro-economic point of view by emphasizing the effects that legislation may have on individual investment decisions by making linkages to economic and corporate theory that explain corporate behaviour. It will be argued that these legal barriers and risks should be reduced along all segments of the supply chain of renewable energy technology in order to decrease the costs of RES, including transaction costs and the costs of capital for RES projects, and thereby facilitate additional investments. Although we focus primarily on international investment law, certain aspects may overlap with international trade law and we therefore emphasize the influence that investment measures may have on international trade. As a result of the micro-economic approach that is adopted, this contribution does not pretend to take into account the complete range of interests which have to be balanced by governments in their decision-making. ${ }^{14}$ The aim of this contribution is thus to analyse how FDI in the RES sector may be increased through the use of international investment law. In this context, the benefits which increased FDI and trade in the RES sector offer to host states will briefly be touched upon.

In section 2 this contribution first discusses a number of risks which RES investors generally encounter and subsequently how contemporary international investment law may reduce these risks and thus promote investments. In order to demonstrate the protection offered by such treaties in current practice, recent arbitration cases which were instigated following regulatory changes to the RES support scheme in Spain are analysed. One of the main observations of this section is that contemporary investment law primarily provides ex-post investment protection and is thus highly reactive in nature. Section 3 will therefore critically reflect on a number of key issues faced by investors which international investment law currently does not (sufficiently) address: market access for foreign investors and the effects of local content requirements. By adopting a micro-economic approach this section includes an analysis of how international law can mitigate the concerns of investors and thus facilitate investments. Section 4 subsequently adopts a macro-economic

13 Shannon Pratt and Roger Grabowski, 'Relationship Between Risk and the Cost of Capital' in Shannon Pratt et al. (eds.), Cost of Capital: Applications and Examples (Hoboken: Wiley, 2014), pp. 70-87; René M. Stultz, 'Globalization, Corporate Finance, and the Cost of Capital', Journal of Applied Corporate Finance, 12/3: 8-25 (1999).

14 The authors thus recognize that legislators may decide to make decisions which harm FDI, either in pursuit of other interests and benefits which the legislator prioritizes or because the legislator wishes to use different legislative tools to obtain RES technology, knowledge and experience. 
approach and briefly examines the effects of liberalization in the RES sector for host states. Particular emphasis is placed on explaining the benefits that may accrue in developing countries, by reference to business practice in the RES sector. Finally, in section 5 we reflect and conclude how international law can play a role in unlocking private capital towards FDI in the renewable energy sector and thereby the realization of the SDGS.

2

\section{Traditional International Investment Law: Protecting Foreign Investments}

Since we aim to determine how investment treaties can remove barriers to FDI and trade in the RES supply chain, it is important to first ascertain the contemporary relevance of investment treaties in the RES sector. Although most bilateral investment treaties (BITs), at least in name, concern investment promotion and protection, the emphasis of these treaties has historically been on investment protection and not so much on effective investment promotion by, for example, the liberalization of FDI. ${ }^{15}$ Arguably though, these treaties can promote FDI by providing protection: If risks associated with an investment are reduced, investors may reduce risk premiums that are added to the required rate of return in their investment decisions and the decreased risks may make a particular investment attractive to a larger pool of investors while at the same time reducing the cost of capital. ${ }^{16}$

Most existing international investment agreements (IIAs) provide for protection against political and regulatory risks faced by investors by regulating the relationship between states and foreign investors in much the same way that administrative law or human rights law does in many jurisdictions by prescribing the rule of law. ${ }^{17}$ As such, IIAs protect investors against undue

15 Krista N. Schefer, International Investment Law - Text, Cases and Materials (Cheltenham: Edward Elgar Publishing, 2016), pp. 318-320.

16 Pratt and Grabowski, 'Relationship Between Risk and the Cost of Capital', pp. 70-87; Alexander Lehmann, 'Country Risks and the Investment Activity of U.s. Multinationals in Developing Countries', IMF wP/99/133, October 1999, https://www.imf.org/ / media/Websites/IMF/imported-full-text-pdf/external/pubs/ft/wp/1999/_wp99133.ashx, accessed 1 November 2018, pp. 21-22; Stephen Arbogast and Praveen Kumar, 'Financing Large Energy Projects' in Betty Simkins et al. (eds.), Energy Finance and Economics: Analysis and Valuation, Risk Management, and the Future of Energy (Hoboken: Wiley, 2013), pp. $33^{2-} 337$.

17 See for example: Susan Karamanian, 'Human Rights Dimensions in Investment Law' in Erika de Wet et al. (eds.), Hierarchy in International Law: The Place of Human Rights 
government interference that adversely affect their investments. However, IIAs only do so for a specific group of entities, namely foreign investors that fall within the scope of each specific IIA. Substantive investment protection standards include, amongst others, non-discrimination principles, no expropriation without compensation, the obligation to provide fair and equitable treatment (FET) - which may include the protection of legitimate expectations and the obligation to provide full protection and security. In addition to granting foreign investors substantive rights, most IIAs also provide for a relatively effective dispute resolution mechanism in the form of Investor-State Dispute Settlement (ISDS) provisions that most often provide for international investment arbitration. Currently, the total number of IIAs exceeds 3.000, which includes BITs as well as multilateral treaties, such as the Energy Charter Treaty (ECT) and the North American Free Trade Agreement (NAFTA). ${ }^{18}$

For investors, the decision whether or not to make an investment depends on a multitude of factors. One of the most important aspects related to any investment decision is an analysis of the risks associated with an investment. The greater the risks associated with an investment the higher the required rate of return, i.e. the minimum return an investor wants to make on an investment. The assessment of risks covers all facets of the project over the entire project lifetime, which can be a monumental task. ${ }^{19}$ Large investments are normally made on the basis of an elaborate assessment, taking into account all risks that can influence the profitability of an investment.

Roughly speaking, identified risks can be dealt with in three ways: They can be retained by the investor, transferred to counterparties or transferred to insurers. ${ }^{20}$ In corporate finance it is more common that risks are retained than when project finance is used..$^{21}$ Of course this depends on the nature of the risk and the costs of transferring risk, as high costs are often the main factor not to

(Oxford: Oxford University Press, 2012), pp. 236-271; Chester Brown, 'Investment Treaty Tribunals and Human Rights Courts Competitors or Collaborators?', The Law and Practice of International Courts and Tribunals, 15/2: 287-304 (2016); Daniel Kalderimis, 'Investment Treaty Arbitration as Global Administrative Law: What this Might Mean in Practice' in Chester Brown et al. (eds.), Evolution in Investment Treaty Law and Arbitration (Cambridge: Cambridge University Press 2011), pp. 145-159.

18 UnCTAD, World Investment Report 2016 (Geneva: UNCTAD, 2016), p. 101.

19 To illustrate, a power developer indicated that his projects are documented through an average of 30.000 pages of tightly drawn contracts although unforeseen and problematic situations are still encountered. John Dewar and Oliver Irwin, 'Project Risks' in Dewar, International Project Finance Law and Practice, p. 85.

20 Gatti, Project Finance in Theory and Practice, p. 43.

21 Ibid. 
transfer risks. When risks are retained, internal processes are set up to monitor and manage the risks. Where project finance is used, the debt agreement includes financial covenants which provide - usually stringent - economic parameters within which the borrower can operate the project. These covenants include requirements regarding the cash flow of the project or the provision of information about certain (financial) events to the lenders, and also allow the lenders to monitor the project company's financial position. ${ }^{22}$ The distinction between corporate and project finance is of great importance here since completely internalized risks, whereby the borrower bears all the risks, are far less likely to be accepted by lenders in a project finance setting than in corporate finance. After all, if a production facility is unable to operate, for example due to an accident, in case of corporate finance it is possible that the company is able to use its other production facilities to comply with its financial obligations while, in the case of project finance, it will technically enter default when the facility is unable to operate for a prolonged period of time. ${ }^{23}$

Of the risks associated with every project, political and regulatory risks are major concerns. ${ }^{24}$ This statement holds true both with regards to investments in developing as well as developed countries. Energy investments are exposed to a relatively high level of political and regulatory risk as energy investments are usually made for the long term and the public and private interests involved, whether fiscal, financial, environmental, technical or social, are usually significant. It is thus not surprising that uncertainty surrounding support policy has been named as a primary factor hindering REs investments. ${ }^{25}$ As a by-product of the long lifetime of most energy projects, economic cycles change, elections are held and other significant political and social changes are expected to occur. In the past, especially investments in the oil and gas sector have been prone to the premature termination of concessions or expropriations without

22 Cox and Holmes, 'Principal Loan Finance Documentation', pp. 296-297.

23 Gatti, Project Finance in Theory and Practice, p. 43.

24 Dewar and Irwin, 'Project Risks', pp. 98-102; Philip Fletcher, 'Approaching Legal Issues in a Project Finance Transaction' in Dewar, International Project Finance Law and Practice, pp. 5-6 and 13-14; Gatti, Project Finance in Theory and Practice, pp. $55^{-56 .}$

25 Frankfurt School UneP Collaborating Centre, 'Global Trends in Renewable Energy Investment - 2012, https://www.circleofblue.org/wp-content/uploads/2012/o6/UNEP_global -trends-in-renewable-energy-investment-June-2012.pdf, accessed 1 November 2018, pp. 12, 19 and 47 . 
compensation. ${ }^{26}$ More recently, the renewable energy sector has also seen its fair share of investment disputes between host states and foreign investors. ${ }^{27}$

Thus far, most investments in renewable energy sources (RES) have been driven by regulation, meaning that jurisdictions where favourable conditions were created for RES investors have received significant amounts of FDI. ${ }^{28}$ Since most forms of RES have not been able to compete on price with more traditional sources of energy, many countries adopted support schemes to incentivize RES investments. However, if the economic viability of an investment depends on support measures, this also exposes the investment to a particular kind of regulatory risk, namely that the support measures will be altered during the lifetime of the facility. In most current RES investment disputes, these issues are at the heart of the dispute: financial support was reduced or altered for various reasons. ${ }^{29}$ Since many RES projects are financed with a significant amount of debt, this means that substantial changes to the cash flow of a project can cause a bankruptcy if financial obligations cannot be honoured. ${ }^{30}$

To exemplify the political and regulatory risks associated with RES investments, which have manifested themselves in several countries, and the way contemporary investment law has dealt with them, the following section will discuss the country where investors were confronted with particularly harsh regulatory changes: Spain.

\subsection{The Application of International Investment Protection Law in Renewable Energy Disputes: The Case of Spain}

In order to give an impression of the practical relevance of rules on investment protection in the RES sector, the regulatory framework of Spain, the subsequent amendments thereto and the consequences for RES investors will be introduced. Subsequently, a brief examination of various arbitral awards involving Spain will follow. It will be concluded that at present, there is a lack of legal certainty in the application of norms of investment treaties.

26 Peter Cameron, International Energy Investment Law - The Pursuit of Stability (Oxford: Oxford University Press, 2010), pp. 3-14.

27 Nikos Lavranos and Cees Verburg, 'Renewable Energy Investment Disputes - Recent Developments and Implications for Prospective Energy Market Reforms' in Martha Roggenkamp et al. (eds.), European Energy Law Report XII (Cambridge: Intersentia, forthcoming 2018).

28 Petri Mäntysaari, EU Electricity Trade Law - The Legal Tools of Electricity Producers in the Internal Electricity Market (Cham: Springer, 2015), p. 445. See also I RENA and CPI, Global Landscape of Renewable Energy Finance, p. 22.

29 Lavranos and Verburg, 'Renewable Energy Investment Disputes'.

3o IRENA and CPI, Global Landscape of Renewable Energy Finance, p. 12. 
In 2007 the Spanish government enacted a very generous RES support scheme, which provided for direct financial support in the form of a FIT. ${ }^{31}$ Royal Decree 661/2007 (RD 661/2007) foresaw in FITs that were granted for the lifetime of a facility, although the FIT was reduced after a given amount of years. ${ }^{32}$ Also, REs generators were granted priority dispatch. ${ }^{33}$ In order for generators to be eligible for support under RD 661/2007, they had to fulfil a registration requirement. ${ }^{34}$

In 2007 it was already noted by one author that RD 661/2007 'guarantees very attractive profitability levels for [renewable electricity] investors. Furthermore, it will continue to be provided even when [RES] plants are fully paidoff, which will entail an unnecessary burden for consumers' ${ }^{35}$ Indeed, under RD 661/2007 some investors in photovoltaic (PV) solar energy were eligible to receive as much as EUR 0,44 per $\mathrm{kWh} .{ }^{36}$ In late 2007 Spanish authorities were aware of the fact that investments in primarily solar energy were increasing rapidly. ${ }^{37}$ On the one hand, one could argue that the policy was successful; it

31 The main purpose of FIT policy is to provide investors certainty by ensuring guaranteed prices for a certain period of time for electricity produced from RES, which can be done in multiple ways, see Toby Couture and Yves Gagnon, 'An Analysis of Feed-in Tariff Remuneration Models: Implications for Renewable Energy Investment', Energy Policy, 38/2: 955-965 (2010).

Although RD 661/2007 did foresee in future tariff adjustments, these revisions were not intended to affect existing investments. See Article 44(3), Royal Decree 661/2007, Legislation Development of the Spanish Electric Power Act, Volume 11, 2009, p. 117. Cees Verburg and Nikos Lavranos, 'Recent Awards in Spanish Renewable Energy Cases and the Potential Consequences of the Achmea Judgment for intra-EU ECT Arbitrations' in Loukas Mistelis et al. (eds.), European Investment Law and Arbitration Review (Leiden: Brill Nijhoff, forthcoming).

33 EU member states are currently held to provide priority dispatch to RES pursuant to Article 16(1)(c) Directive 2009/28/EC of the European Parliament and of the Council of 23 April 2009 on the promotion of the use of energy from renewable sources, but a repeal has been suggested in the winter package. In case electricity production exceeds consumption, priority dispatch requires transmission system operators to minimise the curtailment of electricity produced from RES.

34 Articles 14 and 17 (c), Royal Decree 661/2007, Legislation Development of the Spanish Electric Power Act, Volume 11, 2009, pp. 92-93 and 95.

35 Pablo del Río González, 'Ten Years of Renewable Electricity Policies in Spain: An Analysis of Successive Feed-in Tariff Reforms', Energy Policy, 36/8: 2917-2929 (2008), p. 2926.

36 Charanne and Construction Investments v. Spain, scC Case No. v 062/2012, Award, 21 January 2016, para. 121.

37 Daniel Behn and Ole Kristian Fauchald, 'Governments Under Cross-Fire? Renewable Energy and International Economic Tribunals', Manchester Journal of International Law, 12/2: 117-139 (2015), p. 121. 
has been said that 'Spain alone accounted for over 50 percent of the installed PV solar in the world' in $2008 .^{38}$ On the other hand, one could also argue that if one support scheme attracts $5^{0}$ percent of all PV investments worldwide, it might be too generous and not necessarily be successful, but rather a tremendous financial liability.

A further complicating factor was that the costs of these Fits could not be passed on to final electricity consumers in Spain because the electricity tariff was regulated by the government. The difference between the regulated electricity tariff and the FIT created a so-called 'tariff deficit', which was the amount paid to producers which could not be recouped from consumers. ${ }^{39}$

It has to be noted, however, that generous subsidies were not exclusively the cause of the tariff deficit. The tariff deficit existed before but was exacerbated by the financial and economic crises that had a significant impact on the Spanish economy. ${ }^{40}$ As a result of reduced economic activity, the demand for energy also declined which aggravated the deficit. ${ }^{41}$ According to the rating agency Moody's, the tariff deficit amounted to a cumulative total of EUR 28.8 billion in $2013 \cdot{ }^{42}$

After the 'boom' in RES investments in Spain and the realization that the regulatory framework might not be financially sustainable, several legislative measures were adopted that were aimed at reducing the tariff deficit in the period of 2008 to 2014. Many of these measures have given rise to countless legal proceedings, both domestically and internationally. ${ }^{43}$

In the period of 2008 to 2012 various measures were introduced that adjusted the favourable legal framework. These measures had, amongst others,

38 Ibid.

39 Iñigo del Guayo Castiella, 'Promotion of Renewable Energy Sources by Regions: The Case of the Spanish Autonomous Communities' in Marjan Peeters et al. (eds.), Renewable Energy Law in the EU - Legal Perspectives on Bottom-Up Approaches (Cheltenham: Edward Elgar Publishing, 2014), p. 67.

$40 \quad$ Iñigo del Guayo, 'Energy Law in Spain' in Martha Roggenkamp et al. (eds.), Energy Law in Europe - National, EU and International Regulation (Oxford: Oxford University Press, 2016), p. 1041.

41 Del Guayo Castiella, 'Promotion of Renewable Energy Sources by Regions', p. 67.

42 Global Credit Research, 'Moody's: Spanish Electricity System Heads Toward Sustainability, as Electricity Tariff Deficit Debt Falls', 14 March 2016, https://www.moodys.com/ research/Moodys-Spanish-electricity-system-heads-toward-sustainability-as-electricity -tariff--PR_345353, accessed 1 November 2018.

43 Behn and Fauchald, 'Governments under Cross-Fire?', pp. 122-123. 
the effect of reducing financial support for new plants, ${ }^{44}$ eliminating the FIT from the twenty-fifth year onwards, ${ }^{45}$ introducing new technical requirements aimed at overcoming voltage dips in the network, ${ }^{46}$ limiting the amount of annual hours that PV plants were entitled for support while producing electricity and the introduction of a toll for access to the electricity network, ${ }^{47}$ as well as the introduction of a 7 percent tax on electricity generation which included generation facilities that made use of REs. ${ }^{48}$

More drastic measures followed in 2013 and 2014, which had the effect of completely repealing the legal regime on the basis of which the support was granted. ${ }^{49}$ Ultimately, in June 2014 a new regulatory regime concerning remuneration was laid down which entitled generators to a 'reasonable rate of return' that was 'calculated on the basis of a hypothetical "efficient plant". ${ }^{50}$ The calculation parameters for this regime were established by ministerial order,

44 Royal Decree 1578/2008; Del Río González, 'Ten Years of Renewable Electricity Policies in Spain', p. 2919.

45 In particular Article 3, Royal Decree 1565/2010, Boletin Oficial del Estado, nr. 283, 2010, p. 97428 .

46 Royal Decree 1565/2010, Boletin Oficial del Estado, nr. 283, 2010, p. 97428.

47 Royal Decree Law 14/2010 and Article 2 First Transitory Provision, Royal Decree Law 14/2010, Boletin Oficial del Estado, nr. 312, 2010, p. 106386.

48 Article 8, Law 15/2012, Boletin Oficial del Estado, nr. 312, 2012, p. 88081; Del Guayo, 'Energy Law in Spain', p. 1042; Del Guayo Castiella, 'Promotion of Renewable Energy Sources by Regions', p. 68; Verburg and Lavranos, 'Recent Awards in Spanish Renewable Energy Cases'.

49 First, Royal Decree Law 2/2013 (RDL 2/2013) eliminated the option of a FIP and also changed the mechanism that was used to update FITs. Several months later, Royal Decree Law 9/2013 (RDL 9/2013) was adopted, which amended the provision of the Law of the Electricity Sector of 1997 (LES 1997) that had laid the legal foundation for the creation of the 'Special Regime' on the basis of which the later support schemes were based. Also, RD $661 / 2007$ was repealed and the system of FITs and FIPs was eliminated and replaced by a system that provided 'for 'specific remuneration' based on 'standard' (but not actual) costs per unit of installed power, plus standard amounts for operating costs. Law 24/2013, which was adopted in late 2013 superseded the LES 1997 and 'completely eliminated the distinction between the Ordinary and Special Regimes. See Article 1, Royal Decree Law 2/2013. Article 1, Royal Decree Law 9/2013, Boletin Oficial del Estado, nr. 167, 2013, p. 52106; Article 9 Single Derogatory Provision, Royal Decree Law 9/2013, Boletin Oficial del Estado, nr. 167, 2013, p. 52106; Eiser Infrastructure Limited and Energía Solar Luxembourg S.à r.l. v. Kingdom of Spain, ICSID Case No. ARB/13/36, Final Award, 4 May 2017, paras. 145-146; Verburg and Lavranos, 'Recent Awards in Spanish Renewable Energy Cases'.

5o Article 11, Royal Decree 413/2014, Boletin Oficial del Estado, nr. 140, 2014, p. 43876; Eiser v. Spain, para. 147 . 
which was adopted around the same time.$^{51}$ In the Eiser $v$. Spain case, the remuneration parameters were summarized as follows:

The tariff regime in $\mathrm{RD} 661 / 2007$ is abandoned, substituting a new regime of reduced remuneration based on hypothetical 'standard' investment and operating costs and characteristics of hypothetical 'efficient' plants, with remuneration limited to an operating life of 25 years. Remuneration is calculated based on regulators' projections of the revenues required to attain a prescribed lifetime pre-tax return of $7,398 \%$ based on the hypothetical costs of a hypothetical standard installation. The prescribed rate of return is potentially subject to change every six years. Remuneration is based on capacity, not production, eliminating the incentive potentially available under RD 661/2007 to build more expensive but more productive plants. Remuneration is capped at the hypothetical production of a 'standard plant'. Payments already received by a facility under the prior regime can be credited against the lifetime remuneration due under the new one, thus allowing clawback of 'excess' amounts received under the prior regime. ${ }^{2}$

The 2013 and 2014 measures essentially replaced the old support scheme with a completely new one, where the remuneration parameters are fundamentally different and to a large extent based on hypothetical assumptions that do not take into account the actual and individual characteristics of projects. ${ }^{53}$ Moreover, this new regime was applied to existing facilities. ${ }^{54}$ For existing investments that deviate from the hypothetical assumptions on which the new remuneration scheme is based, the consequences could be very considerable..$^{55}$

\subsubsection{The Application of the Energy Charter Treaty}

In response to all of these changes to the regulatory framework governing electricity production from RES, international investors initiated almost forty ECT arbitrations against Spain, making it the most sued nation under the Ест. Although many of these investors invoked various ECT provisions, their main

51 Ministerial Order IET/1045/2014 even explicitly uses the word 'assumptions': see Annex III, Ministerial Order IET/1045/2014, Boletin Oficial del Estado, nr. 150, 2014, p. 46430.

$5^{2} \quad$ Eiser $v$. Spain, para. 148. Formatting altered by authors.

53 Verburg and Lavranos, 'Recent Awards in Spanish Renewable Energy Cases'.

54 Ibid.

55 Ibid. 
argument is often the same; namely that their legitimate expectations, which are protected under the Ест, have been violated by these regulatory changes. Although one will not find a reference to 'legitimate expectations' in the text of the ECT itself, in ECT arbitration it is a recognized element of the obligation of the state to provide 'fair and equitable treatment' (FET) to foreign investors on the basis of Article 10(1) ECT. ${ }^{56}$

In the currently developing ECT jurisprudence concerning RES disputes, it seems that two distinct legitimate expectations are put forward by investors, although they have been formulated and analysed differently in the various cases. Firstly, that the investor had the legitimate expectation that the regulatory framework on the basis of which the investment was made, often RD 661/2007, would remain in force unchanged. Secondly, that if Spain was required to amend the regulatory framework, investors could have the legitimate expectation that these changes would be implemented within the boundaries of fairness and equitableness. Arbitral awards regarding these two types of legitimate expectations in the context of RES investment disputes will be analysed in the following sections.

\subsubsection{The Legal Stability Expectation}

In Spanish ECT cases concerning regulatory changes in the RES sector, the legal stability argument is usually phrased along the following lines: The investors made an investment on the basis of the existing regulatory framework, usually RD 661/2007 and government documents that promoted the regulatory framework to (foreign) investors. Subsequently, the Spanish state made changes to this support scheme or even completely dismantled it, thereby adversely affecting the investors.

$5^{6}$ Article 10(1) of the Energy Charter Treaty (adopted 17 December 1994; entered into force 16 April 1998), UNTS 2080: 95. Plama Consortium Limited v. Republic of Bulgaria, ICSID Case No. ARB/03/24, Award, 27 August 2008, paras. 176 and 219; Electrabel S.A. v. Republic of Hungary, ICSID Case No. ARB/o7/19, Decision on Jurisdiction, Applicable Law and Liability, 30 November 2012, paras. 7.74-7.79; Electrabel S.A. v. The Republic of Hungary, ICSID Case no. ARB/07/19, Award, 25 November 2015, para. 155; AEs Summit Generation Limited and AEs-Tisza Erömü Kft v. The Republic of Hungary, ICSID Case No. ARB/07/22, Award, 23 September 2010, paras. 9.3.8-9.3.17; AEs Corporation and Tau Power B.V. v. Republic of Kazakhstan, ICSID Case No. ARB/10/16, Award, 1 November 2013, paras. 291, 397-412; Anatolie Stati, Gabriel Stati, Ascom Group sA and Terra Raf Trans Traiding Ltd v. Kazakhstan, sCC Case No. v (116/2010), Award, 19 December 2013, para. 941; Mamidoil Jetoil Greek Petroleum Products Societe S.A. v. Republic of Albania, ICSID Case No. ARB/11/24, Award, 30 March 2015, paras. 705-712. 
In practice, accepting the legal stability argument would essentially mean that 'the FET standard grants investors a freestanding entitlement to the stability of the legal arrangements under which the investment was made. ${ }^{57}$ The consequences of adopting this line of reasoning are therefore significant: Any regulatory change that would make the legal environment less appealing to investors could potentially lead to liability under IIAs. ${ }^{58}$ Given the implications that this argument has for states, the ECT tribunals in the Charanne v. Spain, Antin v. Spain and Eiserv. Spain cases all rejected this argument.

In Charannev. Spain the tribunal refused to acknowledge that a general legal framework could give rise to legitimate expectations that are protected under international law in the absence of a specific representation of the host state that the regulatory framework would not change. ${ }^{59}$ According to the tribunal:

[...] the Claimants could not have the legitimate expectation that the regulatory framework established by RD 661/2007 and RD 1578/2008 would remain unchanged for the lifetime of their plants. Admitting the existence of such an expectation would, in effect, be equivalent to freeze the regulatory framework applicable to eligible plants, although circumstances may change. Any modification in the amount of the tariff or any limitation of the number of eligible hours would then constitute a violation of international law. In practice, the situation would be the same that if the State had signed a stabilisation clause or adopted a commitment to not modify the regulatory framework. The Arbitral Tribunal cannot support such a conclusion. ${ }^{60}$

The tribunals in Eiser v. Spain and Antin v. Spain would make comparable statements. ${ }^{61}$

The awards in the Charanne and Eiser cases were decided and made public in 2016 and 2017 respectively. In that light it is notable that in early 2018 the ECT tribunal in Novenergia v. Spain did accept a claim by investors phrased along similar lines. In essence, the Novenergia tribunal accepted that RD 661/2007

57 Jonathan Bonnitcha, Substantive Protection under Investment Treaties (Cambridge: Cambridge University Press, 2014), p. 184.

58 Ibid.

59 Charanne v. Spain, para. 499.

6o Ibid., para. 503 .

61 Eiserv. Spain, para. 362; Antin Infrastructure Services Luxembourg S.à.r.l. and Antin Energia Termosolar B.V.v. Kingdom of Spain, ICSID Case No. ARB/13/31, Award, 15 June 2018, paras. 530,531 and 538 . 
and several other documents regarding the Spanish RES policy - the very same documents as in the Charanne and Eiser cases - were a credible source to base legitimate expectations on that are protected under the Ест. ${ }^{62}$ This is somewhat surprising given the fact that none of these documents were specifically directed at the investor, something the Novenergia tribunal itself would acknowledge in its award. ${ }^{63}$ Besides deviating from factually comparable cases such as Charanne and Eiser, the Novenergia award deviates from nearly all previous ECT cases concerning legitimate expectations. ${ }^{64}$ This could greatly expand the scope of the ECTS FET standard.

Another case where this argument was accepted was Masdarv. Spain. This investor had invested in three concentrated solar power plants in late 2008 and early 2009. ${ }^{65}$ In this case, the investor contacted the authorities in 2010 while regulatory changes were ongoing and sought confirmation that its projects would be subject to the 2007 regime. ${ }^{66}$ Contrary to other Spanish ECT cases, the project companies of Masdar received explicit confirmation from the authorities that its investments would indeed receive remuneration on the basis of RD 661/2007. ${ }^{67}$ In the light of such factual circumstances, the tribunal considered that the investors could have the legitimate expectation that the benefits of that scheme would remain 'unaltered' ${ }^{68}$ Masdar would eventually be awarded over EUR 64 million in damages.

2.1.3 The Legitimate Expectation that Regulatory Changes will be Implemented within the Boundaries of Fairness and Equitableness The second argument, that a state violates legitimate expectations of investors when regulatory changes exceed the boundaries of fairness and equitableness,

62 Novenergia II - Energy \& Environment (sCA) (Grand Duchy of Luxembourg), SICAR v. The Kingdom of Spain, sCC Arbitration (2015/063), Final Arbitral Award, 15 February 2018, paras. 666-681; Lavranos and Verburg, 'Renewable Energy Investment Disputes'.

$63 \quad$ Novenergia v. Spain, para. 715.

64 Plama v. Bulgaria, para. 176; Electrabel v. Hungary, Decision on Jurisdiction, Applicable Law and Liability, paras. 7.76-7.78; Mohammad Ammar Al-Bahloul v. The Republic of Tajikistan, scc Case No. v (064/2008), Partial Award on Jurisdiction and Liability, 2 September 2009, paras. 200-202; AES v. Hungary, paras. 9.3.17-9.3.18. AES v. Kazakhstan, paras. 289-291.

65 Masdar Solar \& Wind Cooperatief U.A. v. Kingdom of Spain, ICSID Case No. ARB/14/1, Award, 16 May 2018, para. 5 .

$66 \quad$ Ibid., para. 123.

67 Ibid.

68 Ibid., paras. $5^{11-522 .}$ 
is often put forward as a subsidiary argument. In Charanne $v$. Spain, the investors argued as follows:

[...] the Claimants submit in this regard that 'the legitimate expectations of the investor [...] are frustrated, even in the absence of specific commitments, when the receiving State performs acts incompatible with a criterion of economic reasonableness, with public interest or with the principle of proportionality' 69

The tribunal accepted the rationale behind this approach and stated that 'an investor has a legitimate expectation that, when modifying the existing regulation based on which the investment was made, the State will not act unreasonably, disproportionately or contrary to the public interest. ${ }^{70}$ Concerning proportionality, 'the Arbitral Tribunal considers that this criterion is satisfied as long as the changes are not capricious or unnecessary and do not amount to suddenly and unpredictably eliminate the essential characteristics of the existing regulatory framework..$^{71}$

In the end, the Charanne tribunal would also reject this argument since it believed that the 2010 measures, the only measures over which the Charanne tribunal had jurisdiction, merely altered certain aspects of the legal regime without eliminating the fundamental characteristics of the regulatory framework. Nevertheless, as the first ruling in an ЕСT case concerning REs, the award was carefully read by other ЕСт tribunals. The endorsement that regulatory changes may violate the FET standard - even in the absence of representations made by the host State - may have far reaching consequences for ECT contracting parties. In late 2016, an ECT tribunal in the REs case Blusun v. Italy, addressed this issue with reference to the Charanne award. Interestingly, the Blusun tribunal quite openly criticized the proposed standard of review of the Charanne tribunal, which held that regulatory changes should not be implemented unreasonably, disproportionately or contrary to the public interest:

Of the three criteria suggested in Charanne, 'public interest' is largely indeterminate and is, anyway, a judgement entrusted to the authorities of the host state. Except perhaps in very clear cases, it is not for an investment tribunal to decide, contrary to the considered view of those authorities, the content of the public interest of their state, nor to weigh against

\footnotetext{
69 Charanne v. Spain, para. 513.

$70 \quad$ Ibid., para. 514.

71 Ibid., para. 517 .
} 
it the largely incommensurable public interest of the capital-exporting state. The criterion of 'unreasonableness' can be criticized on similar grounds, as an open-ended mandate to second-guess the host state's policies. By contrast, disproportionality carries in-built limitations and is more determinate. It is a criterion which administrative law courts, and human rights courts, have become accustomed to apply to governmental action. ${ }^{72}$

Therefore, the Blusun tribunal held that '[i]n the absence of a specific commitment, the state has no obligation to grant subsidies such as feed-in tariffs, or to maintain them unchanged once granted. But if they are lawfully granted, and if it becomes necessary to modify them, this should be done in a manner which is not disproportionate to the aim of the legislative amendment, and should have due regard to the reasonable reliance interests of recipients who may have committed substantial resources on the basis of the earlier regime.73

On the basis of the Blusun award, one could thus argue that the Ест protects RES investors against disproportionate measures that reduce support to RES investors.

In the Eiser case, the tribunal would come to the conclusion that the regulatory changes exceeded the boundaries of fairness and equitableness in violation of the ECT'S FET standard:

Taking account of the context and of the ECT's object and purpose, the Tribunal concludes that Article 10(1)'s obligation to accord fair and equitable treatment necessarily embraces an obligation to provide fundamental stability in the essential characteristics of the legal regime relied upon by investors in making long-term investments. This does not mean that regulatory regimes cannot evolve. Surely they can. [...] However, the Article 10(1) obligation to accord fair and equitable treatment means that regulatory regimes cannot be radically altered as applied to existing investments in ways that deprive investors who invested in reliance on those regimes of their investment's value. ${ }^{74}$

The tribunal considered that the introduction of a new remuneration methodology for FITs that did not take into account actual characteristics of individual

72 Blusun S.A., Jean-Pierre Lecorcier and Michael Stein v. Italian Republic, ICsID Case No. ARB $/ 14 / 3$, Final Award, 27 December 2016, para. 318.

73 Ibid., para. 319 .

74 Eiserv. Spain, para. 382. 
investments, effectively and retroactively prescribed design standards for facilities built years before. ${ }^{75}$ As a result of this new remuneration methodology, revenues decreased by 66 percent which also adversely affected the value of the investment: while the investor had invested EUR 125 million the value of the investment was reduced to EUR 4 million. ${ }^{76}$ In the end, the tribunal would award Eiser EUR 128 million in damages.

The standard of review as adopted by the Eiser tribunal, which focuses on whether measures eliminated essential characteristics of the regulatory framework, received the approval of the tribunal in Antin v. Spain. ${ }^{77}$ Since the new framework made use of a remuneration methodology that did not provide the FITs on the basis of identifiable criteria, but rather made use of standard assumptions that were based on governmental discretion, the tribunal considered that the regulatory changes exceeded the boundaries of the FET obligation as the regime was not 'aligned to the representations previously made by Spain regarding the stability of the legal and economic regime application to $\mathrm{RE}[\mathrm{s}]$ projects in order to induce investments' in the solar sector. ${ }^{78}$ As a result of violating the ЕСт, Spain was ordered to compensate Antin EUR 112 million in damages.

The Novenergia v. Spain tribunal would address the findings of the Eiser tribunal and disagree with the proposed standard of review.

The Tribunal disagrees with the approach adopted by the arbitral tribunal in Eiser, [...]. In the Tribunal's view, the assessment of whether the FET standard has been breached is a balancing exercise, where the state's regulatory interests are weighed against the investors' legitimate expectations and reliance. It is not simply sufficient to look at the economic effect that the challenged measures have had. Destruction of the value of the investment is clearly determinative in the assessment of whether a state has breached Article 13 [Expropriation] of the ECT, but it is but one of several factors to consider when determining whether a state has breached Article 10(1) of the ECT. Nevertheless, in the Tribunal's opinion, the economic effect on a claimant's investment is an important factor in the balancing exercise pursuant to Article 10(1) as well, as it can go

\footnotetext{
75 Ibid., para. 414.

$76 \quad$ Ibid., paras. 151 and 417.

77 Antin v. Spain, para. 531.

$78 \quad$ Ibid., paras. $562-573$.
} 
towards showing a change in the essential characteristics of the legal regime relied upon by investors in making long-term investments. ${ }^{79}$

Rather, the Novenergia tribunal emphasized that the Spanish measures were so 'radical and unexpected' that they 'fell outside the acceptable range of legislative and regulatory behaviour' as they 'entirely transform[ed] and alter[ed] the legal and business environment under which the investment was [...] made'.80 The resulting 'significant damaging economic effect' on the investment was sufficient to establish a breach of the FET standard. ${ }^{81}$ The Novenergia tribunal thus adopted a slightly different standard of review. For example, concerning the effects of regulatory changes on an investment, the standard of review as proposed by the Novenergia tribunal entails a lower threshold of liability since the measures do not have to destroy the value of an investment, but rather cause significant damaging economic effect upon it. Novenergia would eventually be awarded EUR 53 million in damages.

\subsection{Observations Concerning the Application of Contemporary Investment Treaties in the RES Sector}

On the basis of the Ест awards discussed above, one can conclude that an IIA like the ЕСT can provide effective protection for investors against regulatory changes that alter fundamental characteristics of the existing support scheme, for example by applying new rules to existing investments with the consequence of causing economic damage to investors. This is highly relevant in a sector where many investments still require subsidies for their economic viability. Despite the fact that the importance of financial support is decreasing due to increased competitiveness of RES, subsidized RES generators will remain active in electricity markets for the next decades. Also, reforms in the electricity markets of the European Union (EU) are currently looming with potential consequences for RES investors. For instance, rules on priority dispatch of RES in the EU will most likely change in the near future. ${ }^{82}$ Depending on

\footnotetext{
$79 \quad$ Novenergia v. Spain, para. 694.

8 o Ibid., para. 695 .

$81 \quad$ Ibid.

$82 \quad C f$. Article 16 of the 2009 Renewable Energy Directive of the European Union to Article 20 of the proposed Renewable Energy Directive. Article 16, Directive 2009/28/EC of the European Parliament and of the Council of 23 April 2009 on the Promotion of the Use of Energy from Renewable Sources and Amending and Subsequently Repealing Directives 2001/77/EC and 2003/30/EC [2009] OJ L140/16; Article 20, Proposal for a Directive of the European Parliament and of the Council on the Promotion of the Use of Energy from Renewable Sources (recast), сом(2016) 767 final $/ 2$.
} 
how these rules are implemented in relation to existing investments and the consequences thereof, new RES investment disputes could arise. ${ }^{83}$

As the awards nevertheless also show, the lack of consistency undermines the predictability of the application of the Ест. Of course, this lack of legal certainty and predictability might have adverse consequences for states, as they might become uncertain what legislative changes may be implemented without violating international obligations, as well as for investors who might not be able to predict precisely what is protected under the treaty. In that regard, before IIAs can fulfil their potential of mitigating investments risks, it is desirable that the application of these treaties becomes more predictable.

Of course, not all risks associated with an investment can be addressed by investment protection rules as laid down in IIAs. There are many other risks, such as supply, operation, and technical risks that fall squarely within the sphere of commercial risk that any entrepreneur bears. As such, most contemporary IIAs that provide for investment protection merely provide for protection against political and regulatory risk, as the awards above demonstrate. This means that the IIA regime is highly reactive in nature, which is to say that investors will rely on it after an investment has been made, and a dispute has arisen and, potentially, their investment has already gone south. Discriminatory barriers to investment are often not addressed and the legal framework does not necessarily facilitate investments, it merely protects them once made. In light of these shortcomings, it is not surprising that empirical research shows that there is not a strong correlation between the conclusion of IIAs and flows of FDI. A recent meta-analysis held that a number of studies found that IIAS probably do have some positive influence on flows of FDI while several studies argued to the contrary. ${ }^{84}$ Also, the positive effect was primarily visible in the extractive industries sector and not so much in high-tech sectors. ${ }^{85}$

Because of the emphasis on post-establishment investment protection in contemporary IIAs, foreign investors may thus lawfully be confronted with a variety of rules set by legislators that can increase risks and constitute de facto barriers to investment and trade. This deficiency in contemporary IIAs

\footnotetext{
83 Lavranos and Verburg, 'Renewable Energy Investment Disputes'.

84 Jonathan Bonnitcha, Assessing the Impacts of Investment Treaties: Overview of the Evidence (Winnipeg, MB: IISD, 2017), https://www.iisd.org/sites/default/files/publications/assessing-impacts-investment-treaties.pdf, accessed 1 November 2018, pp. 3-4. As noted in this report, these studies 'face a range of methodological challenges' as a result of which the causality between the conclusion of IIAs and flows of FDI is difficult to prove.

85 Ibid.
} 
constitutes unutilized potential for such treaties to contribute to the realization of the SDGs.

\section{The Way Forward: A Holistic Approach to Investment and Trade in the Renewable Energy Sector}

It is beyond doubt that in order to successfully realize the energy transition to RES, very significant investments are required for decades to come. In order to facilitate these investments, policy makers should aim at creating supportive and predictable legal frameworks; not only domestically but also internationally. Although a vast majority of the investments in RES projects around the globe are financed domestically, the value chain of RES generation equipment and projects is very much internationally organized. ${ }^{86}$ For example, although China is both the largest manufacturer of PV cells and has the highest installed capacity, this does not mean that all Chinese PV modules are purely domestically sourced. ${ }^{87}$ When taking into account chemicals production, electrical components manufacturing, and the production of wafers and crystalline silicon, the picture looks completely different with leading firms based in countries such as Germany, the United States, Norway, South Korea, Austria and Japan. ${ }^{88}$ Original Equipment Manufacturers (OEM) of wind turbines headquartered in China, Germany, the United States, Denmark, and Spain account for over 80 percent of the market. ${ }^{89}$ This means that it is quite

86 OECD, OECD Business and Finance Outlook 2016 (Paris: OECD Publishing, 2016), p. 159; oECD, Overcoming Barriers to International Investment in Clean Energy: Green Finance and Investment (Paris: OECD Publishing, 2015), pp. 59-6o.

87 IEA, Snapshot of Global Photovoltaics Markets 2016, Report IEA PVPS T1-31:2017, http:// www.iea-pvps.org/fileadmin/dam/public/report/statistics/IEA-PVPS_-_A_Snapshot_of _Global_PV_-_1992-2016_1_.pdf, accessed 1 November 2018, pp. 5 and 10. See also Medium, Solar Economics, 'Part 2: Mapping the Global Value Chain', 21 September 2017, https:// medium.com/@solar.dao/solar-economics-part-2-mapping-the-global-value-chain-ec$57 \mathrm{crb} 23 \mathrm{f} 2$, accessed 1 November 2018.

88 Medium, 'Mapping the Global Value Chain'.

89 Paul Dvorak, 'Report: Wind Turbine oems Set for More M\&A as Chinese Companies Take the Lead', 24 March 2016, https://www.windpowerengineering.com/mergers-acquisitions/report-wind-turbine-oems-set-ma-chinese-companies-take-lead/, accessed 1 November 2018. 
likely that international parties will be involved in the value chain of RES projects, even if that project is domestically financed. ${ }^{90}$

Of course, when one argues that states should strive to facilitate RES investments by creating a supportive and predictable international legal framework, the obvious subsequent question is what should such a framework take into account? Arguably, it should take into account the business custom and practice of the RES sector. In particular, it should combine rules governing investment with those governing trade. Since the failure of the International Trade Organization in the late 1940's, the international rules concerning trade and investment have developed almost separately into two almost distinct 'fields' of international law. ${ }^{91}$ In practice, however, trade and investment go hand in hand, especially in an increasingly globalized world where goods are traded in global value chains. ${ }^{92}$

According to the Organisation for Economic Cooperation and Development (OECD), the value chain of RES generation equipment is increasingly globally organised; this means that PV panels and wind turbines contain components that originate from numerous jurisdictions. ${ }^{93}$ Furthermore, it is common

9o Chiara Criscuolo et al., 'Renewable Energy Policies and Cross-Border Investment: Evidence from M\&A in Solar and Wind Energy', срв Discussion Paper 288, 2014, https:// www.cpb.nl/sites/default/files/publicaties/download/dp288-shestalova-renewableenergy-policies.pdf, accessed 1 November 2018, pp. 12 and 15.

91 Mark Wu, 'The Scope and Limits of Trade's Influence in Shaping the Evolving International Investment Regime' in Zachary Douglas et al. (eds.), The Foundations of International Investment Law: Bringing Theory into Practice (Oxford: Oxford University Press, 2014), p. 172. It has to be acknowledged that increasingly comprehensive free trade agreements include rules on trade and investment.

92 On the relationship between trade, investment, and global value chains, see Sébastien Miroudot, Dorothée Rouzet and Francesca Spinelli, 'Trade Policy Implications of Global Value Chains: Case Studies', OECD Trade Policy Papers, No. 161 (2013); OECD, WTO and UnCTAD, 'Implications of Global Value Chains for Trade, Investment, Development and Jobs', 6 August 2013, https://unctad.org/en/PublicationsLibrary/unctad_oecd_wto_2013d1 _en.pdf, accessed 1 November 2018, pp. 21-25; Rainer Lanz and Sébastien Miroudot, 'IntraFirm Trade: Patterns, Determinants and Policy Implications', oECD Trade Policy Working Paper No. 114, 24 June 2011, https://www.oecd-ilibrary.org/docserver/5kg9p39lrwnn-en.pd f? expires $=1543924229 \&$ id $=$ id \& accname $=$ guest $\&$ checksum $=3 \mathrm{D}_{4} \mathrm{~F}_{9} \mathrm{~B}_{95} \mathrm{~B}_{4} \mathrm{CF}_{574 \mathrm{EA}}$ 39A6B FC915 $\mathrm{CE}_{7} \mathrm{E}_{7}$, accessed 1 November 2018; National Board of Trade, 'Global Value Chains and Services - An Introduction', February 2013, https://www.kommers.se/Documents/ dokumentarkiv/publikationer/2013/rapporter/report-global-value-chains-and-services -an-introduction.pdf, accessed 1 November 2018, p. 5 .

93 OECD, Business and Finance Outlook, p. 159; OECD, Overcoming Barriers to International Investment in Clean Energy, pp. 59-6o. 
practice that OEMs of PV panels and wind turbines sell hardware in combination with services contracts that provide for transport, construction, and maintenance. ${ }^{94}$

As the RES sector involves technologies and knowledge which is in the hands of a relatively select group of companies located in a relatively limited number of countries, a failure to acknowledge the interrelatedness between trade in goods and services and investment may raise risks associated with technology, planning, design, and construction as well as raise prices more generally. ${ }^{95} \mathrm{This}$ in turn also means that a barrier to either investment or trade in goods and/or services may de facto become a barrier to all three.

Considering the last decade, it seems that many states have seen the REs industry as an appealing emerging economic 'pie' of which they all want a piece because of its potential to deliver high-tech jobs, research, and development more generally. ${ }^{96}$ Numerous states have enacted protectionist legislation to that end which overlooks the complexities of the value chain of RES generation equipment and project development, undermines economic efficiency and may even have counterproductive effects. ${ }^{97}$ According to the OECD, the use of protectionist legislation, either in the form of local content requirements (LCRs) or the application of trade remedies, affecting the RES sector has been on the rise since 2009. ${ }^{98}$

These measures have the potential of raising the costs of inputs for RES projects, which undermines the competitiveness of RES technologies, while also exposing investors to additional risks, such as unnecessary technological or counterparty risks, which may lead to increased capital and transaction

94 United States International Trade Commission, 'Renewable Energy and Related Services: Recent Developments', Investigation No. 332-534, August 2013, https://www.usitc.gov/ publications/332/pub4421.pdf, accessed 1 November 2018, pp. xix and xx.

Ronald Steenblik and Massimo Geloso Grosso, 'Trade in Services Related to Climate Change: An Exploratory Analysis', OECD Trade and Environment Working Papers 2011/03, 26 May 2011, https://www.oecd-ilibrary.org/docserver/5kgc5wtdgrzw-en.pdf?expires=154 $3924340 \&$ id=id\&accname $=$ guest $\&$ checksum $=787991 \mathrm{DBo1C} 8{ }_{3} \mathrm{C}_{919} \mathrm{E} 83 \mathrm{Ag}_{9} \mathrm{~F}_{96} \mathrm{o}_{7} \mathrm{~F}_{7} \mathrm{~F} 22$, accessed 1 November 2018, p. 4.

96 Joachim Monkelbaan, 'Using Trade for Achieving the SDGs: The Example of the Environmental Goods Agreement', Journal of World Trade, 51/4: 575-603 (2017), p. 584; Ricardo Meléndez-Ortiz and Mahesh Sugathan, 'Enabling the Energy Transition and Scale-Up of Clean Energy Technologies: Options for the Global Trade System - Synthesis of the Policy Options', Journal of World Trade, 51/6: 933-958 (2017), p. 937. OECD, Business and Finance Outlook, pp. 158-159. OECD, Overcoming Barriers to International Investment in Clean Energy, p. 50. 
costs. ${ }^{99}$ Needless to say, the higher the amount REs goods and services have to be imported in a given jurisdiction, the greater the need for a facilitative trade and investment policy. According to the OECD, especially solar and wind projects in the least-developed countries are reliant on imported goods and services because of the lack of a local industry. ${ }^{100}$

The importance of an international investment regime, which provides for the effective liberalization of FDI instead of mere post-establishment investment protection, will be further elaborated by reference to the following specific aspects: market access and investment liberalization, and LCRs imposed by host states.

\subsection{Market Access and Investment Liberalization}

For any investor looking to make an investment, it is of profound importance to examine whether regulatory barriers are in place in a particular jurisdiction. For example, foreign investments may be subject to strict regulation according to national law, which means that significant de facto or de jure barriers may exist. However, in the absence of any commitments to the contrary, states are under no obligation to admit foreign investors or to provide them market access in a non-discriminatory manner. ${ }^{101}$ While the possibility exists for investors to lobby and negotiate market access, possibly in cooperation with home state governments or other interested parties, this is - as a rule - a cumbersome and lengthy process with uncertain outcomes and which, even if successful, significantly increases transaction costs. Transaction costs in this context are the costs associated with a certain undertaking which, if too high, may prevent desirable exchanges from taking place which means that an

99 Trade remedy measures, such as unfair anti-dumping measures, can directly increase the costs of inputs of RES projects as, for example, imported solar panels become more expensive. LCRs can expose investors to unnecessary technological and counterparty risks: Technological risks may increase if foreign investors are compelled to make use of domestic hardware when a country does not possess a REs industry with a proven track record. Likewise, if foreign investors are compelled to cooperate with domestic contractors that lack experience in developing RES projects, risks associated with the investment may increase which is likely to lead to an increased cost of capital.

100 Steenblik and Grosso, 'Trade in Services Related to Climate Change', p. 10.

101 Anna Joubin-Bret, 'Admissions and Establishment in the Context of Investment Protection' in August Reinisch (ed.), Standards of Investment Protection (Oxford: Oxford University Press 2008), p. 10; Rudolf Dolzer and Christoph Schreuer, Principles of International Investment Law (Oxford: Oxford University Press, 2008), pp. 80-81. 
investor might refrain from investing. ${ }^{102}$ In order to resolve issues of market access, IIAs may contain commitments to this end.

However, most of the IIAs that are currently in force, including the ECT and thousands of BITs, do not regulate market access. Rather, they only provide for investment protection for those investments 'which the host State has unilaterally decided to admit'. ${ }^{103}$ This means that those IIAs do not liberalize flows of FDI and that foreign investors may lawfully be confronted with all sorts of measures that obstruct market entrance. In practice this translates into the reality that foreign investors may be completely denied access to a country regardless of its potential for renewable energy and the existence of a BIT. Obviously, if investors are not allowed to enter a country, they cannot and will not make an investment.

Although a minority, there are IIAs that do provide for market access and various treaty drafting techniques exist to that end. The NAFTA is an example, where the non-discrimination regimes as embodied in the national treatment and most favoured nation provisions are extended to the pre-establishment phase of an investment. As stated in Article 1102 NAFTA:

Each Party shall accord to investors of another Party treatment no less favorable than that it accords, in like circumstances, to its own investors with respect to the establishment, acquisition, expansion, management, conduct, operation, and sale or other disposition of investments.

Similar approaches can be found in recent comprehensive trade agreements, such as the Comprehensive and Progressive Agreement for Trans-Pacific Partnership (СРTPP) and the Comprehensive Economic and Trade Agreement (CETA). ${ }^{104}$ The CETA combines this with a provision that very explicitly provides for market access. ${ }^{105}$ In order to balance market access rights with public policy objectives of host states, exceptions to the non-discrimination

102 For more information on transaction costs theory, see Douglas C. North, "Transaction Costs, Institutions, and Economic History' Journal of Institutional and Theoretical Economics 140/1: 7-17 (1984); Oliver E. Williamson, 'The Economics of Organization: The Transaction Cost Approach', American Journal of Sociology 87: 548-577 (1981).

103 Dolzer and Schreuer, Principles of International Investment Law, p. 81.

104 Articles 9.4 and 9.5 of the Comprehensive and Progressive Trans-Pacific Partnership Agreement (adopted 8 March 2018; not yet in force). Articles 8.6 and 8.7 of the Comprehensive Economic and Trade Agreement (European Union-Canada) (adopted 30 October 2016; not yet in force).

105 Article 8.4 of the Comprehensive Economic and Trade Agreement (European Union-Canada). 
rules are often incorporated in the treaty as in practice no state 'will grant unlimited [market] access to foreign investors'. ${ }^{106}$ This statement even holds true for the liberalization of investments within the EU, arguably the most liberal international investment regime in existence. ${ }^{107}$

In practice, negotiating parties to an IIA that does liberalize FDI can do so by, for example, identifying economic sectors to which the non-discrimination regime applies (opt-in system), or in principle apply the non-discrimination regime to all economic sectors subject to certain exceptions (opt-out); with the latter approach most likely to be more liberal, transparent, and ambitious than the former. ${ }^{108}$ Also, even when states decide to allow exceptions to non-discrimination, these exceptions can be subject to far reaching provisions, such as standstill and ratchet clauses. ${ }^{109}$

Common discriminatory barriers to FDI may include restrictions on land ownership by foreigners, domestic equity participation requirements, screening procedures, technology transfer requirements, and economic needs tests. ${ }^{110}$ Non-discriminatory barriers are also manifold, such as a lack of transparency, regulatory unpredictability, excessive bureaucracy, lack of efficient enforcement of laws and regulations, ineffective governance, and a lack of an efficient and independent national judiciary.111

Where it concerns market access for RES investors, the importance of market access for trade in related goods and services in combination with investment cannot be understated, as any RES project will most likely involve

106 Dolzer and Schreuer, Principles of International Investment Law, p. 81.

107 Jeswald W. Salacuse, The Law of Investment Treaties (Oxford: Oxford University Press, 2010), pp. 203-204.

108 Ibid.

109 See for example Article 8.15(1) of the Comprehensive Economic and Trade Agreement (European Union-Canada). On the basis of a standstill clause, non-conforming measures with the non-discriminatory treatment regime may not be amended after the conclusion of the treaty in a way that would increase the inconsistency. On the basis of the ratchet clause, a non-conforming measure that is amended after the entry into force of the agreement - which reduces the inconsistency with the non-discriminatory regime of the agreement - may not subsequently be amended again in a way that increases the inconsistency, not even to the extent as existed at the time the treaty was negotiated.

110 United States International Trade Commission, 'Renewable Energy and Related Services', pp. 2-22; Energy Charter Secretariat, The Energy Charter Investment Facilitation Toolbox (Brussels: Energy Charter Secretariat, 2017), p. 3; Joachim Monkelbaan, 'Trade in Sustainable Energy Services', October 2013, https://www.ictsd.org/sites/default/files/ news/2013/10/trade-in-sustainble-energy-services.pdf, accessed 1 November 2018, pp. 41-42.

111 Energy Charter Secretariat, The Energy Charter Investment Facilitation Toolbox, pp. 3-5. 
imported goods and/or services, although this may vary by technology and country concerned. ${ }^{112}$ Especially with regards to services much progress can be made since the current international trading regime is not very ambitious, which is unfortunate since it has been said that 'the size of sustainable energy services is bigger than the market for related goods.'13 When oEms sell RES hardware in tandem with services, such as construction and maintenance, trade barriers can constitute significant obstacles regardless of the mode in which the service is supplied. ${ }^{114}$ This is all the more pertinent as the expertise in RES technology and related services such as installation, maintenance and decommissioning are not readily available in all countries, while the success of RES projects depends on it. ${ }^{115}$ Especially the inability of RES firms to 'set up a commercial presence in a foreign country or temporarily move services providers there, continue to hamper efforts by providers of renewable energy services to penetrate foreign markets.'16 ${ }^{116}$ that the aforementioned method to supply services is closely related to investment is self-explanatory: Establishing a local commercial presence by definition requires an investment. In the CETA for example, trade in services by establishing commercial presence is therefore regulated through the investment chapter. ${ }^{117}$

\section{2 $\quad$ Local Content Requirements}

Another example which demonstrates that an international investment regime, which is limited to post-establishment investment protection, is insufficient, is formed by LCRs, or trade related investment measures as they are referred to in the context of the World Trade Organization (WTO). ${ }^{118}$ In quite a few states, investors have to meet a specified amount of local content in order

\footnotetext{
112 Steenblik and Grosso, 'Trade in Services Related to Climate Change', pp. 4 and 9.

113 Monkelbaan, 'Trade in Sustainable Energy Services', p. vii.

114 Ibid., p. xx.

115 Steenblik and Grosso, 'Trade in Services Related to Climate Change', p. 4.

116 Ibid.

117 Panagiotis Delimatsis, 'The Evolution of the Eu External Trade Policy in Services - CETA, TTIP, and TiSA after Brexit', Journal of International Economic Law, 20/3: 583-625 (2017), p. 595; Articles 8.4-8.5, Comprehensive Economic and Trade Agreement (European Union-Canada).

118 Ana Paula Cusolito, Raed Safadi and Daria Taglioni, Include Global Value Chains - Policy Options in Trade and Complementary Areas for Gvc Integration by Small and Medium Enterprises and Low-Income Developing Countries (Washington, DC: International Bank for Reconstruction and Development / The World Bank and oECD, 2016), pp. 77-78; 1995 Agreement on Trade-Related Investment Measures (adopted 15 April 1994; entered into force 1 January 1995), UNTS 1868: 186.
} 
to be eligible for a FIT. ${ }^{119}$ In fact, the usage of LCRs in the RES sector has increased since 2009. ${ }^{120}$ These LCRs require the investor to, in one form or another, hire local contractors or use a minimum percentage of local materials and hire a minimum percentage of local employees for their project. These requirements have a significant impact on the risks involved in the different stages of the project. Among the risks which LCRs impact are counterparty or participant risks. These risks concern the necessity to carry out a test to establish the creditworthiness of each of the participants, contractors and equity partners in a project. ${ }^{121}$ LCRs also affect which companies can be dealt with, and thus have a strong impact on these risks depending on the details of the LCRs involved and the financial stability of the relevant companies established in the host country.

In case new RES generation facilities have to be constructed through greenfield investments, pre-completion phase risks come into play which include construction, technological, planning and design risks. ${ }^{122}$ The success of an ontime and on-budget construction strongly depends on the expertise, knowledge and experience of the contractors and the reliability of the technologies and materials used. LCRs thus significantly impact the project, for example when the knowledge and expertise required is not present in the host country to provide the required technologies or construction, installation and maintenance services. The mentioned risks are not limited to the pre-completion phase, but also impact operation, maintenance and possible issues encountered during decommissioning. ${ }^{123}$ Operating risks include performance standards that

119 Jan-Christoph Kuntze and Tom Moerenhout, 'Are Feed-in Tariff Schemes with Local Content Requirements Consistent with wTо Law?' in Freya Baetens and José Caiado (eds.), Frontiers of International Economic Law - Legal Tools to Confront Interdisciplinary Challenges (Leiden: Brill Nijhoff, 2014), p. 151; Matthew D’Orsi, 'Heated Skirmishes in the Solar Sector: Do Solar-Pv Feed-In Tariffs Constitute Trade-Related Investment Measures and Subsidies Prohibited under the wTo Regime?', The American University International Law Review 29/3: 673-716 (2014), pp. 681-682; Mysore Srikar, 'Renewable Energy Programmes in the European Union, Japan and the United States - Compatibility with wTo Law', Centre for WTo Studies (CWS) Working Paper No. 200/4, 27 August 2012, https://papers.ssrn. com/sol3/Delivery.cfm/SSRN_ID2180806_code1800193.pdf?abstractid=2179621\&mirid=1, accessed 1 November 2018.

120 OECD, Business and Finance Outlook, pp. 158-159; OECD, Overcoming Barriers to International Investment in Clean Energy, p. 50.

121 Dewar and Irwin, 'Project Risks', pp. 117-118.

122 Gatti, Project Finance in Theory and Practice, pp. 45-47; McCormick, 'Project Finance', p. 791.

123 The extent to which developers are responsible for decommissioning costs depends per sector and country. 
are not reached, unexpected decreases in efficiency during the lifetime of the operation, and emission standards that are not met. ${ }^{124}$ Practice shows that technological risk can result in complicating factors and therefore increased operational and decommissioning costs. This particularly holds true for energy projects, since they are usually large and complex. Moreover, as great advancements are being made in many RES technologies, such as energy storage or windmills increasing in size, technological risks are abundant in RES projects when they use 'untested' elements or innovative combinations of technologies. Naturally, risks are lower when investors work with contractors, technologies and materials that have a successful track record. Because of the inherent risks and the magnitude of the investments involved in the RES sector, it is the obvious choice for (risk averse) investors to work with experienced parties. ${ }^{125}$

An effective manner for project developers to hedge risks is to require the contractors and the original oEMs to take a minority equity share in the project, which is increasingly common for wind and solar oems. ${ }^{126}$ Many manufacturers of wind turbines and solar modules also provide for the majority of operation and maintenance services in the wind and solar sectors. ${ }^{127}$ In practice, this can mean that a contractor takes a 10 percent equity share worth, for example, EUR 100 million which the contractor stands to lose if the project fails. ${ }^{128}$ This increased exposure is meant to work as an additional safeguard that the contractor will indeed perform conform the agreed timeline and costs. This way, the other project parties can hedge a multitude of risks related to construction and operation. Traditionally, the risks for non-completion, cost overruns, deficiencies and delayed completion were not retained by the project company or the lenders, but rather carried by the contractors or

\footnotetext{
124 Gatti, Project Finance in Theory and Practice, p. 47.

125 Dewar and Irwin, 'Project Risks', pp. 88-9o.

126 Clean Energy Pipeline, 'The European Renewable Energy Investor Landscape', 2014, http://cleanenergypipeline.com/Resources/CE/ResearchReports/The\%2oEuropean\%20 Renewable\%2oEnergy\%2oInvestor\%2oLandscape.pdf, accessed 1 November 2018, p. 11.

127 United States International Trade Commission, 'Renewable Energy and Related Services', p. xix.

128 Recently, lenders are less hesitant towards taking construction risks in the renewable energy sector as a result of the increased experience with technologies such as wind and solar PV and the experience gained by both the contractors and lenders in these sectors. In both corporate and project finance a balance is made between an increased contracting price for transferring risk to the contractor, taking out separate insurance policies and assuming the risks.
} 
the sponsors. ${ }^{129}$ When the contractors carry the risk and are responsible for the decision on the most suitable technology, chances are that they will choose tried and tested technologies to limit their risks. ${ }^{130}$ When the sponsors make the decision, the chosen contractor and technology supplier may not coincide. ${ }^{131}$ This increases risks especially when technology of different OEMs is combined, as the choice may turn out to be unfeasible in practice while it may have been solid in theory. Where LCRs are in place, sponsors may not be able to work with sufficiently knowledgeable and experienced contractors and suppliers and thus be forced to take decisions and risks they otherwise would not. RES projects have been perceived as high in technological risk because of the innovative character of the technologies used. ${ }^{32}$ Hence, LC Rs increase the cost of capital where they force developers to make use of products and contractors without a proven track record which exposes the project to additional risks. These risks have a significant impact because the whole project has failed from a technical point of view if performance tests fail. ${ }^{133}$ In addition, LCRs increase transaction costs as developers - which are required to work with local personnel, materials and services - will have to overcome an information deficiency to establish the availability, experience and expertise of local suppliers, which may be difficult and expensive considering physical distances and language barriers.

In this manner, the use of LCRs can adversely affect a project, especially when the required knowledge and expertise in technology and personnel is not available in the host country. Even in case it is, the LCRs impose transaction costs as they force companies to carry out due diligence and market research in the host country which may not be necessary if they were allowed to work with partners of their choice, with whom they have previous work experience. For these reasons, it is not surprising that international investors have labelled

129 Dewar and Irwin, 'Project Risks', pp. 87-89. Gatti, Project Finance in Theory and Practice, p. 47. The sponsors are the equity partners in a project company, thus those holding the shares of the project company.

130 Gatti, Project Finance in Theory and Practice, p. 46; Dewar and Irwin, 'Project Risks', p. 90.

131 Gatti, Project Finance in Theory and Practice, p. 46.

$132 \mathrm{Ibid}$. As a result of the risks involved, where risk averse investors are involved, such as pension funds, unknown technologies would not be used. The use of less understood technologies will also be less prevalent and where used increase the cost of capital. Allan Marks and Jenna Darler, 'International Projects - Sector Focus Section D - Renewable Energy', in Dewar, International Project Finance Law and Practice, p. 200.

133 Gatti, Project Finance in Theory and Practice, p. 46. 
LCRs as 'the main policy impediment to international investment across the solar and wind-energy value chain'. ${ }^{134}$

Besides creating barriers to trade and investment in the RES sector, LCRS can also form a potential regulatory risk associated with an investment. In Russia, for example, the required level of local content may be changed ex post facto by the authorities, even in relation to existing investments. ${ }^{135}$ In the worst-case scenario this could mean that a project loses its entitlement to financial support because the raised LCR is not met by the facility while, once completed, it becomes very difficult - both technically as well as financially - to increase the amount of local content.

Of course, the impact of LCRS on RES may differ from technology to technology. In the case of solar panels, for example, one can easily assemble solar panels in one country and ship them worldwide in a container while in the case of wind turbines it might be more convenient to establish a local subsidiary or joint venture in a market because of the complexities associated with the transport, export and installation of wind turbine towers, nacelles, and blades.

The financial consequences of LCRS can be demonstrated by reference to the LCRs in the FIT schemes of the Canadian provinces of Quebec and Ontario. According to one study, these LCRs have increased the costs of installed wind capacity with approximately 'USD 386 per kilowatt of electric capacity', amounting to 14 percent of the total costs per kilowatt of installed capacity; this made Canadian wind capacity significantly more expensive than wind turbine capacity in the United States. ${ }^{136}$ Translated to the costs of a $600 \mathrm{MW}$ wind farm, which can power up to 785.000 households and reduce $\mathrm{CO}_{2}$ emissions by 1,25 million ton per year, an LCR with similar impact would increase the cost of the project by USD 231 million. ${ }^{137}$ In that regard, policy alignment between green policy objectives and industrial policy objectives is desirable. ${ }^{138}$

\footnotetext{
134 OECD, Overcoming Barriers to International Investment in Clean Energy, p. 50.

135 Anatole Boute, Russian Electricity and Energy Investment Law (Leiden: Brill Nijhoff, 2015), p. 527 .

136 Gary Hufbauer and Jeffrey Schott, Local Content Requirements - A Global Problem (Washington, DC: Peterson Institute for Economic Studies 2013), pp. 71-73.

137 To get to this number: $386 \%$ 1.00o (to get the additional cost per $\mathrm{MW}$ instead of $\mathrm{KW}$ ) $=$ 386.000. 386.000*600 (to get the additional costs for a wind project of $600 \mathrm{MW}$ ) $=$ 231.60o.0oo. For the statistics of the wind farm, see http://geminiwindpark.nl/feiten-cijfers.html, accessed 1 November 2018. It should be noted that the total costs for the 600 MW offshore wind farm Gemini were EUR 2.99 billion, while the more recent $700 \mathrm{MW}$ wind farm Borssele III and IV cost closer to EUR 1.5 billion.

${ }_{13} 8$ In fact, it has been argued that removing LCRs can increase output and employment in countries that maintain such measures: Monkelbaan, 'Using Trade for Achieving the
} 
Contrary to the international trade regime, where LCRS in RES schemes have been challenged successfully and effectively, ${ }^{139}$ provisions in existing IIAS regarding LCRs have proven to be largely ineffective. This is due to the fact that the investment protection provisions in IIAS - including those on LCRS only apply to government measures that were adopted after an investment was made, due to the non-retroactive application of treaties. ${ }^{140}$ In a sector where investments are still to a large extent regulatory driven, this means that investors are not able to challenge aspects of regulatory frameworks that have been adopted prior to the investment, even if it in principle violates international obligations.

An interesting example of a recent Free Trade Agreement (FTA) that addresses LCRS in the RES sector is the EU-Vietnam FTA which contains a specific chapter on 'non-tariff barriers to trade and investment in renewable energy generation..141 This chapter explicitly prohibits LCRs that affect 'the other

SDGs', p. 590; Veena Jha, 'Removing Trade Barriers on Selected Renewable Energy Products in the Context of Energy Sector Reforms: Modelling the Environmental and Economic Impacts in a General Equilibrium Framework', October 2013, https://www.ictsd. $\mathrm{org} / \mathrm{sites} /$ default/files/downloads/2013/12/removing-trade-barriers-on-selected-renewable-energy-products-in-the-context-of-energy-sector-reforms.pdf, accessed 1 November 2018, p. 32.

139 Within the context of the WTO, the Agreement on Trade Related Investment Measures (TRIMS Agreement) specifies that such requirements are contrary to the national treatment obligation of the General Agreement on Tariffs and Trade (GATT). See CanadaCertain Measures Affecting the Renewable Energy Generation Sector and Canada - Measures Relating to the Feed-in Tariff Program, WT/DS412/AB/R WT/DS426/AB/R, Reports of the Appellate Body, 6 May 2013; India - Certain Measures Relating to Solar Cells and Solar Modules, WT/DS456/AB/R, Report of the Appellate Body, 16 September 2016; Article 2(1) of the 1995 Wто Agreement on Trade Related Investment Measures (adopted 15 April 1994, entered into force 1 January 1995), UNTS 1868: 186; Simon Lester, Bryan Mercurio and Arwel Davies, World Trade Law - Text, Cases and Commentary (Oxford: Hart Publishing, 2014), p. 671 .

140 Articles 5, 10(11) and 11 of the Energy Charter Treaty; Articles 1106 and 1107 of the North American Free Trade Agreement (United States-Canada-Mexico) (adopted 17 December 1992; entered into force 1 January 1994), ILM 32: 289. See also Mesa Power Group, LLC v. Government of Canada, UNCITRAL, PCA Case No. 2012-17, Award, 24 March 2016, paras. 320-335; Cees Verburg, 'Local Content Requirements in Renewable Energy Schemes Government Procurement or a Violation of International Obligations?', International Energy Law Review 35/5: 185-197 (2017), pp. 190-197.

141 Chapters 8 and 14 of the EU-Vietnam Free Trade Agreement (European Union-Vietnam) (adopted 17 October 2018; not in force), http://trade.ec.europa.eu/doclib/press/index .cfm?id=1437, accessed 1 November 2018. 
Party's products, service suppliers, investors or investments.' ${ }^{142}$ Also, mandatory local equity participation requirements are prohibited subject to a few exceptions. ${ }^{143}$ Finally, it also states with regards to technical standards and regulations, that the contracting parties shall make use of international standards to the extent possible. Nevertheless, the obligations arising under the chapter on renewable energy generation are merely enforceable under the inter-state dispute settlement mechanism and can, as such, not be enforced by private parties. ${ }^{144}$

In the previous sections, it was argued that liberalizing trade and investment in the entire value chain of the RES sector can contribute to lower costs of RES which should facilitate the deployment of Res technologies. In doing so, the authors primarily adopted a micro-economic approach by analysing measures from the perspective of an investor. Since most RES technologies are currently in the hands of a limited number of companies, from primarily developed countries, this instinctively would lead to the conclusion that the benefits of trade and investment liberalization would be harvested by companies from developed countries. Since trade and investment agreements are to be concluded on the basis of reciprocity, an equilibrium which reflects the interests from all countries involved has to be reached. Hence, one has to identify the benefits that liberalization would entail for host states. Although this section deviates from the general micro-economic approach adopted in this article, the authors feel it is important to underline certain macro-economic benefits that may be associated with liberalization as the narrative is incomplete without a discussion thereof.

Even if a country is only marginally involved in the value chain of RES technology, project development and operation offers plenty of opportunity to reap local economic benefits: 'Downstream' activities in the PV sector are more labour intensive than 'upstream' activities, such as module manufacturing. ${ }^{145}$

\footnotetext{
142 Ibid., Chapter 14, Article 4(1)(a).

143 Ibid., Chapter 14, Article 4(1)(b).

144 Ibid., Chapter 13.

145 EY, 'Solar PV Jobs and Value Added in Europe', November 2017, https://www.ey.com/ Publication/vwLUAssets/EY-solar-pv-jobs-and-value-added-in-europe/\$FILE/EY-solar -pv-jobs-and-value-added-in-europe.pdf, accessed 1 November 2018, p. 9; Ferruccio Ferroni and Robert Hopkirk, 'Energy Return on Energy Invested (ERoEI) for Photovoltaic
} 
IRENA, for example, estimates that in the case of PV projects, PV modules and inverters account for 40 percent of the costs of the project. ${ }^{146}$ Balance of system costs account for the remaining 60 percent, which covers non-module hardware (cables, grid connection, racking and mounting, safety and security, and monitoring and control), installation costs (mechanical and electric installations, inspections, and ground preparation), and certain 'soft costs' (application for financial support, permitting, system design, acquisition and financing, and operation costs). ${ }^{147}$ Wind energy may offer even more potential as a local assembly site is often preferred due to the challenges associated with transporting large wind turbine components, such as the tower, nacelle and blades.

Services associated with RES projects provide the clearest economic opportunity for countries that are barely integrated in the value chain of RES hardware. OEMs often sell generation equipment in combination with services in their contracts, by providing for transport, construction and maintenance services. ${ }^{148}$ The reason that trade in goods and services in the RES sector are intrinsically intertwined is related to the high tech nature of the sector: It has been said that the deployment of Res technology lies 'around the top of the complexity ladder'.149 This means that the purchaser of a wind turbine will most likely not only be interested in the physical hardware, but also in the knowledge and skills required to deploy and operate a wind turbine. Consequently, 'they seek to acquire these goods in combination with ancillary services such as installation, technical support, training and maintenance. ${ }^{150}$ To

Solar Systems in Regions of Moderate Insolation', Energy Policy, 94: 336-344 (2016), p. 339; Monkelbaan, 'Trade in Sustainable Energy Services', pp. 32-35.

146 IRENA, Renewable Energy Benefits - Leveraging Local Capacity for Solar PV (Abu Dhabi: IRENA, 2017), p. 10.

147 IRENA, The Power to Change: Solar and Wind Cost Reduction Potential to 2025 (Abu Dhabi: IRENA, 2016), p. 31.

148 United States International Trade Commission, 'Renewable Energy and Related Services', pp. xix and xx; Meléndez-Ortiz and Sugathan, 'Enabling the Energy Transition and Scale-Up of Clean Energy Technologies', p. 944; Tilak Doshi, 'Sector Study on Environmental Services: Renewable Energy', October 2017, https://www.apec.org/-/media/APEC/ Publications/2017/10/Sector-Study-on-Environmental-Services-Renewable-Energy/217 _PSU_Environmental-Services_Renewable-Energy.pdf, accessed 1 November 2018, pp. 3-5.

149 Jehan Sauvage and Christina Timiliotis, 'Trade in Services Related to the Environment', OECD Trade and Environment Working Papers 2017/o2, 9 May 2017, https:/www .oecd-ilibrary.org/deliver/dc99bf2b-en.pdf?itemId=\%2Fcontent\%2Fpaper\%2Fdc99bf2b -en\&mimeType=pdf, accessed 1 November 2018, p. 9.

150 Ibid. 
put the RES goods and services sectors in perspective: It has been said that the market value for RES services is estimated at twice the size of RES goods. ${ }^{151}$ Also, the less mature a market for RES goods and related services is in a given country, the more inputs will have to be imported to successfully develop a project. ${ }^{152}$ According to the OECD, wind and solar projects in the least-developed countries are particularly reliant on imported goods and services because of the lack of a local industry. ${ }^{153}$ In countries which lack the highly skilled labour force required for the development of RES projects, imports can overcome the skill gap in the short term while contributing to the development of a local RES services sector in the long term. ${ }^{154}$ In practice, the establishment of a local commercial presence by foreign RES services providers is the most important method to supply services. ${ }^{155}$ From a development perspective, the establishment of local subsidiaries by foreign REs companies offers interesting opportunities as research shows that these companies often rely on local personnel. ${ }^{156}$ This also means that there are many opportunities for local job creation, transfer of skills and knowledge, and local partnerships. ${ }^{157}$ Especially for the operation and maintenance phase of a project, employing local personnel is often more cost efficient than constantly relying on foreign personnel. Besides establishing a local presence, the presence of foreign natural persons is also a common mode of services supply in the RES sector. ${ }^{158}$ According to the OECD, 'the temporary presence of highly skilled foreign personnel and the

$15^{1}$ Monkelbaan, 'Using Trade for Achieving the SDGs', p. 584.

152 Louis Tse and Oluwatobi Oluwatola, 'Evaluating Renewable Energy Technology Transfer in Developing Countries: Enabling Factors \& Barriers', Journal of Science Policy \& Governance 6/1: 1-10 (2015), p. 6.

153 Steenblik and Grosso, 'Trade in Services Related to Climate Change', p. 10.

154 International Labour Organization and European Union, 'Research Brief - Investment in Renewable Energy Generates Jobs - Supply of Skilled Workforce Needs to Catch Up', http://www.ilo.org/wcmsp5/groups/public/---ed_emp/---ifp_skills/documents/publication/wcms_168354.pdf, accessed 1 November 2018, pp. 6-7.

155 United States International Trade Commission, 'Renewable Energy and Related Services', pp. 2-19; Sauvage and Timiliotis, 'Trade in Services Related to the Environment', p. 10; Camilla Prawitz and Magnus Rentzhog, 'Making Green Trade Happen - Environmental Goods and Indispensable Services', December 2014, https://www.kommers.se/Documents/dokumentarkiv/publikationer/2014/Making-Green-Trade-Happen_webb.pdf, accessed 1 November 2018, p. 17 .

${ }_{15} 6$ Sauvage and Timiliotis, 'Trade in Services Related to the Environment', p. 11; Doshi, 'Sector Study on Environmental Services', p. 29.

157 Sauvage and Timiliotis, 'Trade in Services Related to the Environment', p. 27; Monkelbaan, 'Trade in Sustainable Energy Services', p. 33.

$15^{8}$ Doshi, 'Sector Study on Environmental Services', p. 6. 
establishment of a foreign commercial presence may provide opportunities for person-to-person communication and learning by doing.'.59 Given the controversial nature of this mode of services supply, as it relates directly to labour and immigration policies, barriers to trade in services through this mode are manifold. ${ }^{160}$

The liberalization of trade and investment in the RES sector is thus expected to also create opportunities for technology sharing and capacity building, in line with SDG $17 .^{161}$ For any country which aspires integration in the global value chains of RES technology - which should be beneficial in terms of SDG 8 concerning employment and economic growth as set out above and central to realize SDGS 7 and 13 concerning sustainable energy for all and the promotion of RES to mitigate emissions and combat climate change - building up local capacity and human resources in this area is indispensable. In turn, and in line with SDG 7.A, RES trade and investment liberalization may also enhance international cooperation - especially between private parties - which can facilitate access to RES technology concerning RES goods and services. Considering the urgency with which investments in RES are required in light of climate change and the difficulties which have characterized traditional technology sharing, providing access to foreign investors allows the host state to move forward. The aforementioned benefits which the host state thus enjoys may be a multitude greater than those potentially gained from the introduction of LCRS and the consequently more limited inflow of investments.

\section{$5 \quad$ Conclusion}

Developing renewable energy projects is paramount to the realization of various SDGs. Financing the required energy transition before 2050 has been estimated to require USD 3.5 trillion annually. ${ }^{162}$ These investments must be made across the globe, as all countries have to transition towards a system in which

\footnotetext{
159 OECD, 'Managing Request-offer Negotiations under the GATs: the Case of Energy Services', TD/TC/WP(2003)24/FINAL, 5 November 2003, p. 15.

16o Sauvage and Timiliotis, 'Trade in Services Related to the Environment', p. 11; Prawitz and Rentzhog, 'Making Green Trade Happen', p. 17.

161 See for example: Sébastien Miroudot, 'The Linkages between Open Services Markets and Technology Transfer', OEcD Trade Policy Papers No. 29, 27 January 2006, https://www .oecd-ilibrary.org/docserver/723726052723.pdf?expires=1543927395\&id=id\&accname $=$ guest\&checksum=8DC3688497 $\mathrm{B}_{41137} \mathrm{~B}_{23} \mathrm{~F}_{17} \mathrm{BC} 2 \mathrm{~A} 841 \mathrm{FA}$, accessed 1 November 2018, in particular pp. 16-21 and 46.

162 International Energy Agency, Perspectives for the Energy Transition, p. 8.
} 
the energy consumed originates from modern and sustainable energy sources as aimed for by SDG 7.1.

The latest statistics are, however, disconcerting. In 2017, global energy investments were down, for the third consecutive year, to USD 1.8 trillion while investments in the RES sector were down by 7 percent. ${ }^{163} \mathrm{~A}$ recent report by the United Nations indicates that global flows of FDI across all economic sectors were down by 23 percent in 2017 in comparison to $2016 . .^{164}$ The report observed increased hostility towards FDI and stagnation in investments in global value chains. ${ }^{165}$ In light of the recent international political tensions concerning investment and trade, the prospects are sobering.

International law can nevertheless play an important role in attracting foreign investment and lowering transactions costs and the cost of capital. In the quest to unlock the private capital necessary to finance an energy transition, research has shown that limiting legal, regulatory and political risks is instrumental to attract investors. Practice in the past years has shown that legal certainty cannot be guaranteed in developing nor developed countries where it concerns the legal framework governing electricity production from RES. As the Spanish cases demonstrate, changes in the regulatory framework and especially in the financial support offered to the project can have devastating effects on the financial viability of RES projects that are often very vulnerable to significant changes in cash flow. In these cases, IIAs can provide for effective investment protection. Nevertheless, in order to mitigate perceived and actual investment risks it is desirable that the application of existing IIAs becomes more predictable. Otherwise, it is difficult to see how IIAs can actively promote investment by protecting it.

Besides promoting FDI by protecting it, there are multiple other areas where IIAs can have an impact by removing barriers to investment that adversely affect flows of FDI and trade in the RES supply chain. Ideally, a supportive and predictable international legal framework concerning RES investments would cover all stages of the supply chain of renewable energy, not just project development or the post-establishment protection thereof. This is particularly relevant since empirical evidence demonstrates that IIAs which are limited to ex post investment protection may only have a marginal effect on flows of FDI. An area which should receive much more attention in practice and discourse

163 International Energy Agency, World Energy Investment 2018 (Bonn: IEA, 2018), https:// webstore.iea.org/world-energy-investment-2018, accessed 1 November 2018, p. 11.

164 United Nations Conference on Trade and Development, World Investment Report 2018, UNCTAD/WIR/2018 (Geneva: United Nations, 2018), pp. xi-xii.

165 Ibid. 
is that of market access. International investment law can play a vital role in allowing for market access by foreign investors. Investment treaties can further promote investments by limiting the ability of states to adopt protectionist legislation which increases the cost of RES projects. Since 2009 the use of protectionist measures, either in the form of LCRs or the application of trade remedies, affecting the RES sector has been on the rise. Motivated by the desire to create or protect local jobs in an emerging industry with great potential, many states have adopted trade barriers that in most cases will lead to increased prices by reducing economic efficiency. Instead of devoting efforts to obtain the largest possible piece which the economic renewable energy 'pie' has to offer, states would be better advised to increase the size of the 'pie' as much as possible by creating an international legal framework which facilitates trade and investment in the RES sector.

Over the last few years, research and innovation in the REs sector has contributed significantly to lower costs to the extent that RES are nearly pricecompetitive with alternative sources of energy in some jurisdictions. Moreover, a number developers of large scale projects have been awarded licenses without requiring any subsidies. From the moment that subsidies are no longer required, one might expect that the integration of RES will no longer be primarily regulatory driven, but also market driven. In order to reach this tipping point as soon as possible and unleash the market forces in the pursuit of climate change mitigation, barriers to international trade and investment which from a micro-economic point of view are troublesome, should be avoided. International investment law, ideally in combination with rules on trade in comprehensive FTAs, can contribute to the realization of such conditions through ensuring market access, prohibiting protectionist measures and providing investment protection.

\section{Acknowledgements}

The authors would like to express their gratitude to Prof. Dr. M.M.T.A. Brus, Dr. R.C. Fleming, Dr. A. Rachovitsa and M.M.E. Hesselman, LLM, and the reviewers for their valuable feedback on earlier drafts of this article. Any errors remain our own.

Cees Verburg would like to acknowledge that his $\mathrm{PhD}$ research has benefitted from the support of the Dutch Energy Law Association (NeVER) and Stibbe. 